\title{
Carbon stock in aboveground biomass of vegetation at the High Tatra Mts. twelve years after disturbance
}

\author{
Bohdan Konôpka ${ }^{1,2 *}$, Jozef Pajtík ${ }^{1}$, František Málišs, ${ }^{1,3}$, Vladimír Šebeň ${ }^{1}$, Miriam Malová ${ }^{1}$ \\ ${ }^{1}$ National Forest Centre - Forest Research Institute Zvolen, T. G. Masaryka 2175/22, SK - 96092 Zvolen, Slovak Republic \\ ${ }^{2}$ Czech University of Life Sciences Prague, Faculty of Forestry and Wood Sciences, Kamýcká 176, \\ CZ - 16521 Praha 6-Suchdol, Czech Republic \\ ${ }^{3}$ Technical University in Zvolen, Faculty of Forestry, T. G. Masaryka 24, SK-960 53 Zvolen, Slovak Republic
}

\begin{abstract}
The paper focused on the estimation of aboveground biomass and its carbon stock in the vegetation cover on the territory of the High Tatras twelve years after a large-scale wind disturbance. Besides biomass quantification of main plant groups (i.e. trees and ground vegetation) we considered plant components with special regard to carbon rotation rate. The measurements were performed on two transects each containing 25 plots sized $4 \times 4 \mathrm{~m}$. Height and stem diameter of all trees on the plots were measured and used for biomass estimation. To quantify the biomass of ground vegetation, six subplots sized $20 \times 20 \mathrm{~cm}$ were systematically placed on each plot and the aboveground biomass was harvested. The plant material was subjected to chemical analyses to quantify its carbon concentration. The study showed that while the wind disturbance caused dramatic decrease of carbon stock, young post-disturbance stands with abundant ground vegetation, represented large carbon flux via litter fall. Twelve years after the wind disturbance, the trees contributed to carbon stock more than the ground vegetation. However, the opposite situation was recorded for the carbon flux to litter that was related to the dominance of annual plants in the above-ground biomass of ground vegetation. The carbon stock in the biomass of young trees and ground vegetation represented about 8,000 $\mathrm{kg}$ per ha. The young stands manifested a dynamic growth, specifically the aboveground biomass increased annually by one third. The results confirmed different carbon regimes in the former old (pre-disturbance) and sparse young (post-disturbance) stands.
\end{abstract}

Key words: wind disturbance; carbon in biomass; evergreen and deciduous trees; ground vegetation; foliage fall

Editor: Peter Surový

\section{Introduction}

Climate change is not only an environmental issue, but recently it has been become a serious "civilisation problem". It can have huge negative consequences on human being welfare or even on human existence all over the world (Moran et al. 2010). Climate change is to main extent caused by the increasing of $\mathrm{CO}_{2}$ in the atmosphere which is prevailingly induced by combustion of fossil fuels. A significant contribution to this process is made by the changes in the landscape use, especially in the form of deforestation, a problem typical for developing countries (MacDicken et al. 2015). Luckily, the oceans as well as terrestrial vegetation cover are able to absorb more $\mathrm{CO}_{2}$ than they usually emit. Forest ecosystems are the second largest pool of carbon after the oceans. For instance, Dixon et al. (1994) estimated that as much as $80 \%$ of aboveground and $40 \%$ of belowground (soil, litter, roots) terrestrial carbon is fixed in forests.
It is evident that sustainable development of forests and increasing wood stocks are becoming more ecological than an economical task. Carbon sequestration is currently the most important component of forest ecosystem services (Thorsen et al. 2014). At the same time, carbon sequestration in the tree biomass and in the soil can be partly controlled via forest management. The management should focus on forest protection against harmful agents, stimulation of wood increment and preservation of forest soils.

Increasing forest disturbances in temperate forests triggered by climate change (Seidl et al. 2011) emphasised the need for new knowledge about possible preventive measures that would support the decision making process of forest management. Forest destruction caused by windstorm or other harmful agents brings besides other problems the negative effect on the carbon balance in the landscape (e.g. Dale et al. 2001). Destruction of for- 
est stands means the loss of some parts of carbon stocks in tree biomass (Lindroth et al. 2009). Furthermore, it stimulates carbon emission from the forest soils, and this problem is most relevant in the case of uprooted trees and disturbed soil medium (Liechy et al. 1997). Restitution to the former state (before the disaster episode) takes a couple of decades. Duration of this reversible process is related to time periods of forest regeneration and soil reclamation, while both are regulated by post-disturbance forest management (Fischer et al. 2002). Forest ground vegetation changes rapidly after forest disturbance and in early-successional stages it is formed by non-woody vegetation (Swanson et al. 2010). Consequently, carbon fluxes are also highly dynamic. Although ground vegetation sequestrates some carbon and ecosystem productivity recovers very fast (Williams et al. 2013), from the long-term perspective it is not as efficient as tree cover and often delays or slow down forest regeneration (Hansen 2014).

In general, forest growing stocks (i.e. carbon pool) have been gradually increasing in Slovakia. Specifically, the stock of Slovak forests increased by $7.7 \%$ in the last decade (Ministry of Agriculture and Rural Development 2016). However, the last few decades in Europe have been characterised not only by increasing volume but also by increasing frequency of disturbance processes. In Slovakia, the incidental felling during the last decade made as much as 42 million $\mathrm{m}^{3}$ of calamity wood, which was about $53 \%$ of the total annual cut (Kunca et al. 2016). An extraordinarily large windstorm disturbance was recorded in 2004. The windstorm heavily damaged especially spruce stands. These were subsequently infested by bark beetles resulting in mortality of large forest complexes. Another large scale wind disturbance occurred in 2014 and again, the most serious damages were found in spruce forests. The most intensive wind and bark beetle damage to forests was in the High Tatra Mountains (Nikolov et al. 2014; Økland et al. 2016). There, a considerable part of old forest stands was destroyed and colonised particularly by non-woody ground vegetation (Šoltés et al. 2010; Máliš et al. 2015). Later, the postdisturbance areas were covered by sparse young forest stands with ground vegetation in treeless gaps. In spite of the fact that many large post-disturbance areas currently exist in Slovakia, there is very little information on biomass of their ground vegetation. There are no works focused on carbon stock in post-disturbance vegetation that includes all kinds of plants, i.e. trees and ground vegetation species.

This paper aims at estimating the aboveground biomass and carbon stock in vegetation cover on the territory of the High Tatra Mountains twelve years after the salvage logging that occurred after the wind disturbance in 2004. Besides the quantification of the main vegetation groups (i.e. trees and ground vegetation) we attempted to estimate the biomass of plant components grouped with respect to their carbon rotation rate.

\section{Material and methods}

\subsection{Site and stand description}

Our research activities focused on a post-disturbance area arisen after an intensive windstorm that occurred on $19^{\text {th }}$ November 2004 in the High Tatra Mountains. The storm damaged mostly forests at altitudes between 700 and $1,400 \mathrm{~m}$ a.s.l. The disturbance of the forests concentrated prevailingly in a continual belt oriented in a west-east direction and the affected area was approximately $35 \mathrm{~km}$ long and $5 \mathrm{~km}$ wide (Šebeň 2011). The wind-disturbed area was managed in three different ways with regard to the degrees of nature protection: from fully-processed calamity wood, through partly-processed calamity wood, up to absolutely untreated parts left exclusively to natural succession. The substantial part of the calamity wood was processed in the years 2005 and 2006. Alike calamity wood processing, forest regeneration was also implemented with regard to the degrees of nature protection in the form of planting, natural regeneration and combination of both approaches. Soil preparation for planting of seedlings was performed manually (hole digging by a hoe).

In 2016 (i.e. in the tenth or eleventh growing season after the salvage logging), the area was prevailingly covered by young forests that originated from both natural regeneration and planting. Open areas among the young forest stands were covered by species adapted to forest clearings, particularly by grasses, herbs and shrubs. The forest soils on the post-disturbance area are mainly cambisols and podzols. The bedrock is predominantly formed by fluvio-glacial sediments of granodiorites. The climate is characterised by low mean annual temperatures (around $4.0^{\circ} \mathrm{C}$ ), high precipitation amounts (about $1,000 \mathrm{~mm}$ ) and over 120 days of snow cover (Vološčuk et al. 1994).

To study the carbon stock in trees and ground vegetation, two research transects - one near the site called "Danielov dom" (hereinafter as DD transect) and another one close to the Horný Smokovec village (hereinafter as HS transect) were established. The forests at the localities are managed by the State Forests of the Tatra National Park. Both sites belong to the territory with the lowest degree of nature protection. Thus, the post-disturbance management at these sites was represented by full-area processing of calamity wood and combined (both planting and natural regeneration) reforestation.

The transects are located in the central part of the disturbed belt. The orientation of both transects is from Northwest to Southeast. The altitude of the DD transect varies between $970-1000$ m.a.s.l and that of the HS transect between 920 and 950 m.a.s.l. The transects were $4 \mathrm{~m}$-wide, on which $4 \mathrm{~m}$-long plots for tree measurements were placed and were isolated by $8 \mathrm{~m}$-long gaps without any measurements to ensure that the plots were independent entities. The total length of the DD transect as well as the HS transect was $300 \mathrm{~m}$, i.e. each transect 
comprised 25 plots. The corners of each plot were fixed with wooden pegs hammered in the soil. All young trees occurring on the plots higher than $10 \mathrm{~cm}$ were labelled with a code written on a metallic tag.

\subsection{Measurements and calculations}

The field measurements of trees were performed in the first half of the growing season 2016 (after the entire new leaves were out). We recorded species, tree height and diameter at stem base $\left(\mathrm{d}_{0}\right.$ hereinafter $)$ for all labelled trees on the plots. Altogether, about 380 and 320 individuals were measured at the DD transect and HD transect, respectively.

The standing stocks of the tree aboveground biomass as well as its components (stem, branches and foliage) were estimated from tree measurements (height and diameter $\mathrm{d}_{0}$, i.e. independent variables) using speciesspecific allometric relations; see also Konôpka et al. (2015). The stock was calculated separately for each transect, first at a plot level (as a sum of all trees on the plot), then as a mean value from the 25 plots.At the same time, two groups of tree components were considered: (1) foliage with fast turnover (shortly fixed carbon) and (2) stem plus branches with slow turnover (carbon fixed for a long period). In addition to biomass standing stock of trees, we attempted to estimate the amount of biomass (carbon) annually "lost" from the living trees in form of the annual foliage fall.In the case of deciduous species (broadleaved and larch), the annual foliage fall equals the foliage stock. As for spruce trees, the annual foliage fall was calculated as $1 / 5$ of their autumn standing stock (see e.g. Schmidt-Vogt 1977; Sander \& Eckstein 1994) and for pine as $1 / 3$ of the needle stock in autumn (Konôpka et al. 2003). To estimate the carbon amount in tree foliage, the concentrations of this element were taken from our previous work dealing with the same sites (Konôpka et al. 2016).

The measurements of ground vegetation were performed in August 2016 - the month with the seasonal biomass stock peak. In order to estimate the average standing biomass of ground vegetation, six subplots sized $20 \times 20 \mathrm{~cm}$ were placed at each plot using the randomised selection of spots. Altogether, there were 150 sampling subplots per transect. Prior to biomass sampling, all plant species were identified and recorded at the plot level, and their frequency and cover were estimated at the transect level. The frequency was calculated from the species occurrence on 25 plots (for instance, if the species grew on 10 plots, its frequency at the transect was $40 \%$ ), and the cover was estimated as an average from non-zero numbers of the plots (for example, if the species was not present on 4 plots, the average was calculated from the values on 21 plots, where it occurred).

From each subplot, all present vascular plants except trees were collected. The sampled aboveground biomass was categorised according to the plant life span to: annual (living for a year), biennial (living for two years), and perennial (living for more than two years). Then, the foliage of biennial and perennial plants with the life span of one year (e.g. foliage of Vaccinium myrtillus) was separated and added to the group of annual (i.e. one-year) biomass. Thus, plant biomass was divided into three groups with regard to the period of carbon fixation in biomass of living plants, i.e. one year, two years and over two years. Then, the six samples (coming from the six subplots) originating from the same plot were merged into one mixed sample. Thus, each plot was characterised by three samples representing three different periods of carbon fixation in biomass of living plants. The plant biomass was ovendried to obtain its constant dry matter (48 hours under $85^{\circ} \mathrm{C}$ ) and weight with precision $\pm 0.001 \mathrm{~g}$. The dry matter was subjected to chemical analyses (dry combustion method performed by Flash EA 1112 elemental analyser) to quantify carbon concentration. Since the differences in carbon concentrations between the transects were insignificant, single (i.e. the average of 50 plots) values were used to represent carbon concentration in plants with one year, two years and over two years period of carbon fixation in living biomass.

The standing stock of the plants was calculated separately for each transect as an average value from 25 plots (merged biomass from 6 subplots) considering the groups with one year, two years and over two years period of carbon fixation in living biomass. The biomass was scaled up to a hectare and the carbon amount was estimated with regard to its concentration in a specific group of plants (one year, two years and over two years period of carbon fixation in living biomass).

Data archiving and manipulation was performed in Excel, calculations and analyses were done in Statistica 10.0 .

\section{Results}

The basic stand characteristics (expressed as average values for all plots together) were very similar on both transects (Table 1). While the number of trees and basal area were larger at the DD transect, the mean stem diameter and especially tree height were larger at the HS transect. This contrasting situation was caused mainly by the clearing cut which was performed at the HS transect by the forestry practice in the year 2015 . The cut reduced the number of trees, especially of broadleaved species such as Salix caprea and Sorbus aucuparia. Since the cut aimed more at smaller trees, mean diameter and height increased because they were calculated from larger trees unaffected by cut. The transects differed from each other in their tree species composition (Fig. 1 and $2)$. The DD transect was characterised by the dominance of evergreen species (61.2\%), while the HS transect had more deciduous species (60.0\%). The species composi- 
Table 1. Basic stand characteristics (average value and standard deviation) for the Danielov dom (DD) transect and Horný Smokovec (HS) transect in 2016. Basal area was calculated using stem base diameter.

\begin{tabular}{lcccc}
\hline \multicolumn{1}{c}{ Transect } & $\begin{array}{c}\text { Number of trees } \\
{\left[10^{3} \text { per ha] }\right.}\end{array}$ & $\begin{array}{c}\text { Diameter d } \\
{[\mathrm{mm}]}\end{array}$ & $\begin{array}{c}\text { Loreys height } \\
{[\mathrm{cm}]}\end{array}$ & $\begin{array}{c}\text { Basal area } \\
{\left[\mathrm{cm}^{2} \mathrm{~m}^{-2]}\right.}\end{array}$ \\
\hline Danielov dom & $9.35 \pm 13.38$ & $50 \pm 27$ & $320 \pm 151$ & $12.1 \pm 10.0$ \\
Horný Smokovec & $7.94 \pm 12.58$ & $52 \pm 45$ & $381 \pm 174$ & $9.6 \pm 9.0$ \\
\hline
\end{tabular}

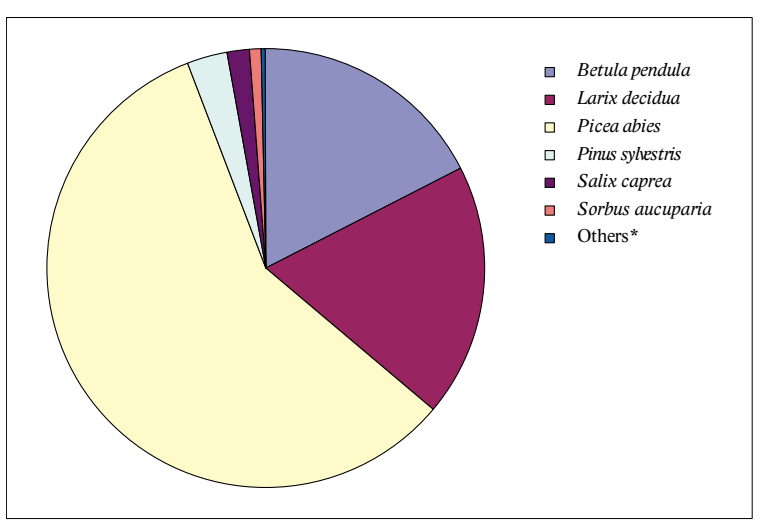

Fig. 1. Average tree species composition (calculated from 25 plots) expressed from basal area at the Danielov dom transect. * Acer pseudoplatanus, Populus tremula, and a variety of Alnus and Salix genus

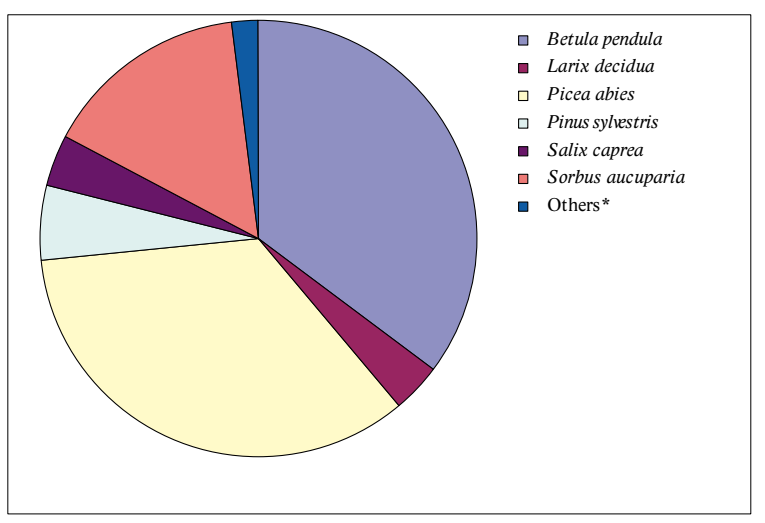

Fig. 2. Average tree species stand composition expressed from basal area (calculated from 25 plots) at the Horný Smokovec transect.

*Acer pseudoplatanus, Populus tremula, and a variety of Alnus and Salix

tion of ground vegetation also slightly differed between the transects, but in both cases they represented later successional stages of post-disturbance forest vegetation (i.e. nearly no presence of ruderal species). The most abundant species which contributed to the total biomass most are shown in Table 2.

The chemical analyses showed that the carbon concentration in foliage varied among tree species from 46.4\% (Salix caprea) to $51.1 \%$ (Picea abies; Table 3). As for ground vegetation, its carbon concentration (excluding root systems) varied from $47.6 \%$ in annual plants to $51.8 \%$ in perennial plants.
Table 2. Frequency and average non-zero cover of ground vegetation species estimated on 25 plots per each transect (each plot was characterised by one mixed sample, generated from six harvested areas - subplots). Only species with frequency above $20 \%$ are listed (the total cover of those with frequency lower than $20 \%$ did not reach $5 \%$ ). The species are divided into three groups depending on the life span of their biomass and ordered by the sum of cover values at both transects.

\begin{tabular}{|c|c|c|c|c|}
\hline \multirow{2}{*}{$\begin{array}{c}\text { Species grouped } \\
\text { by lifespan }\end{array}$} & \multicolumn{2}{|c|}{ Danielov dom transect } & \multicolumn{2}{|c|}{ Horný Smokovec transect } \\
\hline & frequency & cover & $\begin{array}{l}\text { frequency } \\
{[\%]}\end{array}$ & cover \\
\hline \multicolumn{5}{|l|}{ One-year biomass } \\
\hline Calamagrostis villosa & 28 & 18.6 & 100 & 69.5 \\
\hline Calamagrostis arundinacea & 96 & 35.4 & 52 & 3.5 \\
\hline Avenella flexuosa & 96 & 16.5 & 84 & 7.5 \\
\hline Luzula luzuloides & 88 & 3.2 & 72 & 2.3 \\
\hline Agrostis capillaris & 20 & 3.8 & 8 & 1.3 \\
\hline Maianthemum bifolium & 88 & 2.2 & 88 & 2.9 \\
\hline Carex pallescens & 24 & 0.7 & 4 & 4.0 \\
\hline Epilobium angustifolium & 84 & 2.6 & 80 & 1.2 \\
\hline Juncus effusus & 8 & 1.0 & 24 & 2.1 \\
\hline Athyrium filix-femina & 24 & 1.9 & 28 & 1.0 \\
\hline Veronica officinalis & 44 & 2.0 & 16 & 0.4 \\
\hline Galeopsis bifida & 52 & 1.5 & 28 & 0.8 \\
\hline Melampyrum pratense & 68 & 1.7 & 24 & 0.6 \\
\hline Fragaria vesca & 20 & 1.3 & 4 & 1.0 \\
\hline Luzula pilosa & 24 & 1.6 & 12 & 0.7 \\
\hline Hypericum maculatum & 48 & 1.2 & 36 & 0.9 \\
\hline Oxalis acetosella & 56 & 1.3 & 12 & 0.7 \\
\hline Carexpilulifera & 28 & 1.4 & 8 & 0.6 \\
\hline Solidago virgaurea & 44 & 0.6 & 44 & 0.7 \\
\hline Dryopteris dilatata & 36 & 0.5 & 28 & 0.3 \\
\hline Senecio ovatus & 4 & 0.5 & 28 & 0.2 \\
\hline \multicolumn{5}{|l|}{ Two-year biomass * } \\
\hline Rubus idaeus & 34 & 25 & 25 & 10 \\
\hline \multicolumn{5}{|l|}{ More-year biomass* } \\
\hline Vaccinium myrtillus & 92 & 10.9 & 80 & 11.7 \\
\hline Calluna vulgaris & 32 & 1.4 & 72 & 1.6 \\
\hline Vaccinium vitis-idaea & 20 & 1.3 & 8 & 0.8 \\
\hline Sambucus racemosa & 4 & 0.1 & 28 & 0.6 \\
\hline
\end{tabular}

Explanatory note: * The parts of biennial and perennial plants living for only one year (e.g. foliage of Rubus idaeus, Vaccinium myrtillus etc.) were separated and added to the group of one-year biomass.

Table 3. Carbon turnover of plant biomass and carbon concentration by tree species and grouped plants of ground vegetation.

\begin{tabular}{lcc}
\hline $\begin{array}{c}\text { Tree species (foliage only) or group } \\
\text { of ground vegetation }\end{array}$ & $\begin{array}{c}\text { Carbon turnover } \\
\text { [proportion per year] }\end{array}$ & $\begin{array}{c}\text { Carbon concentra- } \\
\text { tion [\%] }\end{array}$ \\
\hline Betula pendula & 1.0 & 51.0 \\
Larix decidua & 1.0 & 48.4 \\
Picea abies & 0.2 & 51.1 \\
Pinus sylvestris & 0.3 & 50.9 \\
Salix caprea & 1.0 & 46.4 \\
Sorbus aucuparia & 1.0 & 49.4 \\
\hline Ground vegetation - 1-year & 1.0 & 47.6 \\
Ground vegetation - 2-years & 0.5 & 49.9 \\
Ground vegetation - over 2-years & less than 0.5 & 51.8 \\
\hline Note: carbon concentrations for tree species were taken from Konôpka et al. (2016), and for \\
ground vegetation were obtained from the chemical analyses performed in this study.
\end{tabular}

We found huge differences (up to tenfold) in biomass, and thus also in carbon stock, between the plots at both the DD transect (Fig. 3) and the HS transect (Fig. 4). At most plots, the aboveground biomass of trees prevailed over the biomass of ground vegetation. At some plots, the contribution of ground vegetation to total biomass was very low (e.g. $3 \%$ at plot 23 on the HS transect). On the other hand, four plots (e.g. plot 4 at the DD transect) were treeless, i.e. ground vegetation made $100 \%$ of plot biomass. We found only weak negative relationship 


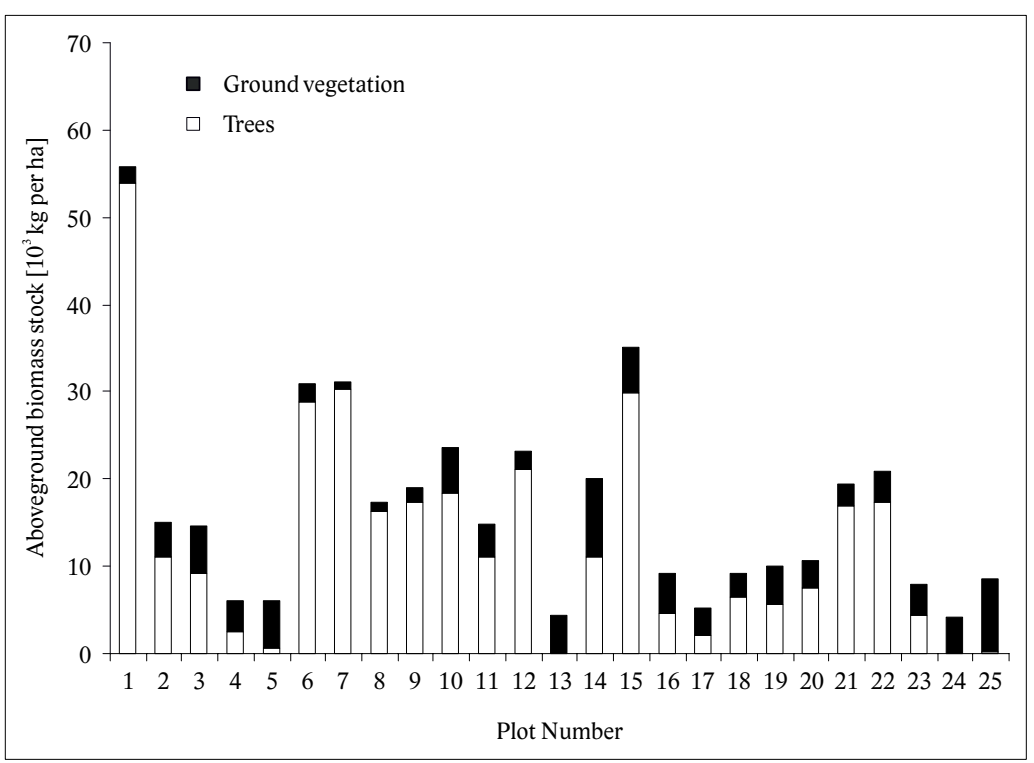

Fig. 3. Aboveground biomass in trees and ground vegetation at the Danielov dom transect.

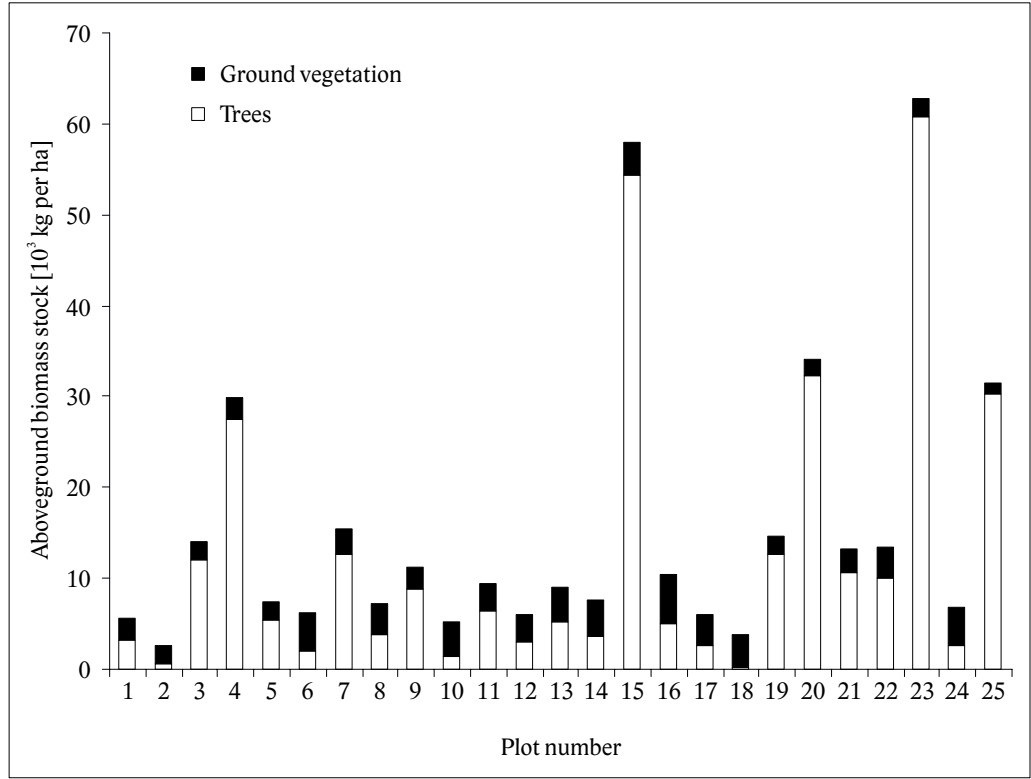

Fig. 4. Aboveground biomass in trees and ground vegetation at the Horný Smokovec transect.

$\left(\mathrm{R}^{2}=0.18\right.$; results not shown in this paper) between the biomass of trees and ground vegetation what may suggest only mild influence of tree cover on ground vegetation community.

The total carbon amount fixed in the aboveground tree biomass was $6,566 \mathrm{~kg}$ per ha and 6,241 $\mathrm{kg}$ per ha at the DD transect and the HS transect, respectively (Table 4 and Table 5). While the contribution of foliage to the total aboveground biomass of trees was $25 \%$ at the DD transect, its share at the HS transect was only $17 \%$. The differences are most probably related to contrasting tree species composition at the transects. As for the ground vegetation, slightly larger carbon amount was at the DD transect $(1,851 \mathrm{~kg}$ per ha; Table 4$)$ than at the HS transect
(1,448 kg per ha; Table 5). The results showed that the carbon amount in the tree aboveground biomass was 3.5 times (DD transect) or 4.3 times (HS transect) higher than in the ground vegetation. The reverse situation was in the carbon flux of the annual foliage fall (Table $6)$. The carbon in the annual foliage fall from the trees represented only $43 \%$ (transect DD) and $44 \%$ (transect HS) of the carbon in the annual ground vegetation fall. At the DD transect, the amount of carbon in the annual tree foliage fall was $614 \mathrm{~kg}$ per ha, while the carbon amount in the annual ground vegetation fall was $1,442 \mathrm{~kg}$ per ha. Similar amounts of carbon, specifically $547 \mathrm{~kg} \mathrm{C}$ per ha in the annual tree foliage fall and $1,257 \mathrm{~kg}$ in the annual ground vegetation fall were found at the HS transect. 
Table 4. Carbon amount in the aboveground woody parts (i.e. stem and branches) and foliage of trees and in ground vegetation at the Danielov dom transect.

\begin{tabular}{lccc}
\hline \multirow{2}{*}{$\begin{array}{c}\text { Tree species or ground vegeta- } \\
\text { tion }\end{array}$} & \multicolumn{3}{c}{ Carbon stock [kg ha $\left.{ }^{-1}\right]$} \\
\cline { 2 - 4 } & in woody parts & in foliage & together \\
\hline Betula pendula & 1,449 & 153 & 1,602 \\
Larix decidua & 1,140 & 180 & 1,320 \\
Picea abies & 2,173 & 1261 & 3,434 \\
Pinus sylvestris & 108 & 35 & 143 \\
Salix caprea & 30 & 11 & 41 \\
Sorbus aucuparia & 14 & 4 & 18 \\
Other broadleaved & 6 & 2 & 8 \\
\hline Trees together & 4,920 & 1,646 & 6,566 \\
\hline Ground vegetation - 1-year & - & - & 1,262 \\
Ground vegetation - 2-year & - & - & 359 \\
Ground vegetation - over 2-year & - & - & 230 \\
\hline Ground vegetation together & - & - & 1,851 \\
\hline
\end{tabular}

Table 5. Carbon amount in aboveground woody parts (i.e. stem and branches) and foliage of trees and in ground vegetation at the Horný Smokovec transect.

\begin{tabular}{lccc}
\hline \multicolumn{1}{c}{ Tree species or } & \multicolumn{3}{c}{ Carbon stock $\left[\mathrm{kg} \mathrm{ha}^{-1}\right]$} \\
\cline { 2 - 4 } \multicolumn{1}{c}{ ground vegetation } & in woody parts & in foliage & together \\
\hline Betula pendula & 2,874 & 265 & 3,139 \\
Larix decidua & 206 & 28 & 234 \\
Picea abies & 1,078 & 519 & 1,597 \\
Pinus sylvestris & 163 & 58 & 221 \\
Salix caprea & 90 & 21 & 111 \\
Sorbus aucuparia & 768 & 98 & 866 \\
Other broadleaved & 61 & 12 & 73 \\
\hline Trees together & 5,240 & 1,001 & 6,241 \\
\hline Ground vegetation - 1-year & & & 1,225 \\
Ground vegetation - 2-year & - & - & 64 \\
Ground vegetation - over 2-year & & & 159 \\
\hline Ground vegetation together & - & - & 1,448 \\
\hline
\end{tabular}

The results proved contrasting contributions of evergreen and deciduous tree species vegetation to carbon stock versus the annually transferred carbon from biomass to necromass (i.e. foliage fall; Fig. 5). Interestingly, the contributions of all tree species to the total carbon stock in the aboveground plant biomass were similar at both transects ( $78 \%$ and $81 \%)$. The differences between the transects were found in the contribution of evergreen and deciduous tree species to the carbon stock, since at the DD transect the evergreen tree species prevailed over the deciduous species, while at the HS transect the situation was reverse. At the same time, the contribution of tree species to the carbon amount in the annual plant fall was very similar at both transects (about 30\%).

Table 6. Carbon flux from plant biomass in the form of annual aboveground fall at the transects of Danielov dom and Horný Smokovec.

\begin{tabular}{lcc}
\hline \multicolumn{1}{c}{ Tree species or } & \multicolumn{2}{c}{ Annual carbon flux $\left[\mathrm{kg} \mathrm{ha}^{-1}\right]$ on the transect } \\
\cline { 2 - 3 } ground vegetation & Danielov dom & Horný Smokovec \\
\hline Betula pendula & 153 & 265 \\
Larix decidua & 180 & 28 \\
Picea abies & 252 & 104 \\
Pinus sylvestris & 12 & 19 \\
Salix caprea & 11 & 21 \\
Sorbus aucuparia & 4 & 98 \\
Other broadleaved & 2 & 12 \\
\hline Trees together & 614 & 547 \\
\hline Ground vegetation - 1-year & 1,262 & 1,225 \\
Ground vegetation - 2-year & 180 & 32 \\
Ground vegetation - over 2-year & unknown & unknown \\
\hline Ground vegetation together & 1,442 & 1,257 \\
\hline
\end{tabular}

The differences between the tree species were found also in the share of carbon in the foliage fall to the total carbon amount in the aboveground biomass (Fig. 6). The largest value (13\%) was found for Larix decidua and the lowest value for Picea abies (7\%). Moreover, we expressed the annual carbon fall per unit of basal area for each species. Again, the largest value was estimated for Larix decidua ( $82 \mathrm{~kg}$ per $\left.\mathrm{m}^{2}\right)$ and the lowest value $(34 \mathrm{~kg}$

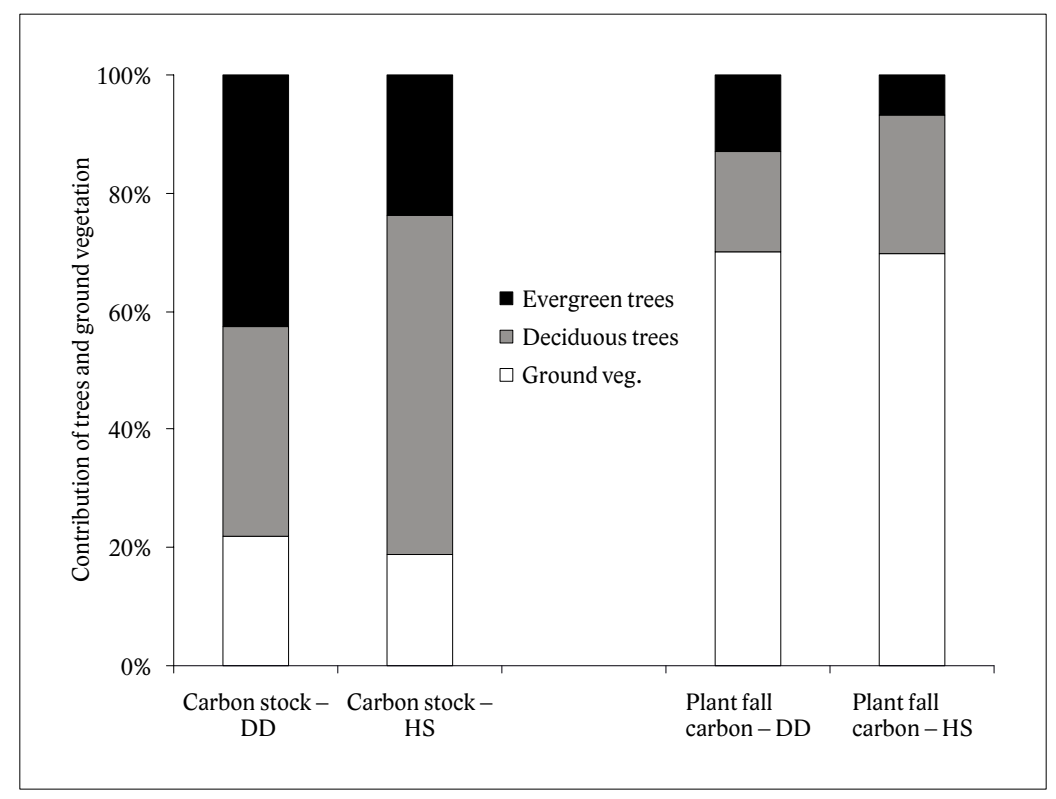

Fig. 5. Contribution of trees (grouped as evergreen and deciduous) and ground vegetation to total carbon stock and to carbon annually transferred via plant fall at the Danielov dom (DD) and Horný Smokovec (HS) transect. 


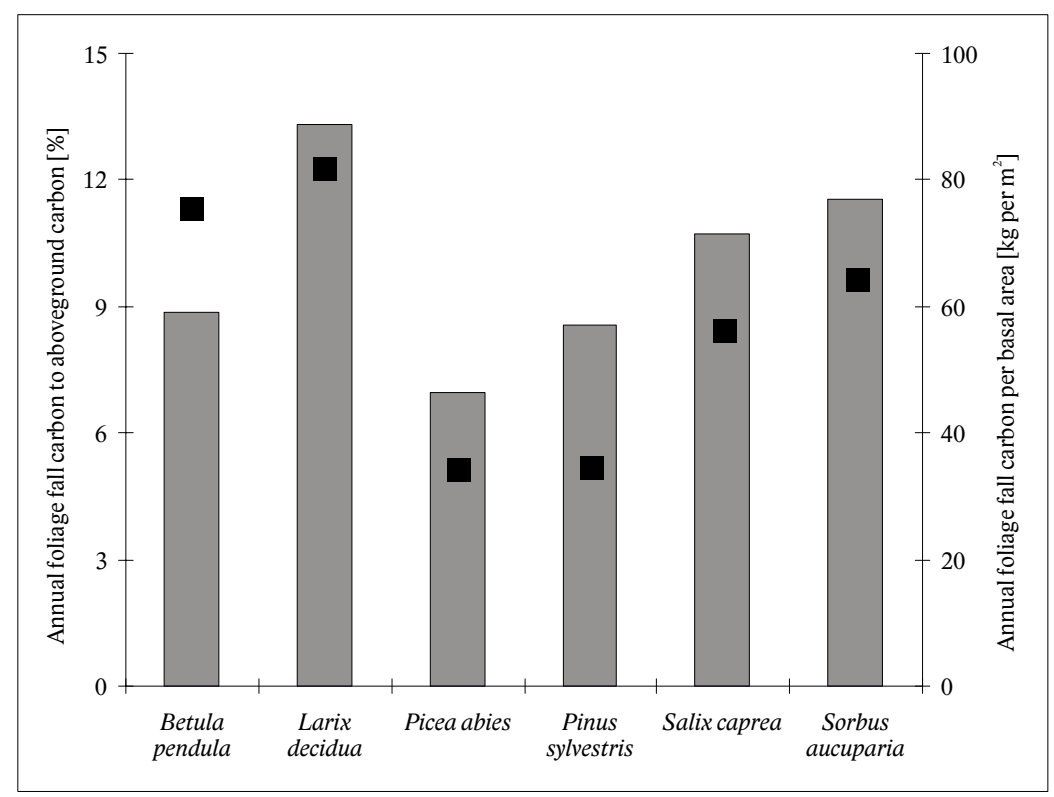

Fig. 6. Carbon in annual foliage fall (i) as a ratio to total aboveground biomass carbon (left y-axis and grey bars) and (ii) per unit of basal area (right y-axis and black squares) in each tree species for both transects together.

per $\mathrm{m}^{2}$ ) for Picea abies. These indicators reflect an efficiency for carbon storage in biomass, i.e. which part of carbon in tree biomass is lost via foliage fall.

Our previous results brought figures on the carbon stock (Table 7) fixed in the aboveground tree biomass of spruce-dominant forest complexes in the central part of the High Tatra region (state to 1997; see Konôpka et al.

Table 7. Contribution of components to total aboveground tree carbon in pre-disturbance forest stands in the High Tatra region - state to 1997 (Konôpka et al. 2016, modified).

\begin{tabular}{lcc}
\hline \multicolumn{1}{c}{ Tree component } & Carbon amount $\left[\mathrm{kg} \mathrm{ha}^{-1}\right]$ & Carbon contribution [\%] \\
\hline Foliage & 4,557 & 6.1 \\
Branches & 3,891 & 5.2 \\
Stem & 66,605 & 88.7 \\
\hline Aboveground parts & 75,053 & 100.0 \\
\hline
\end{tabular}

2016 for more details). Since the results contained not only the information about the total aboveground parts but also about the specific tree components, we could use those for a detailed comparison with post-disturbance young stands (comments are in the Discussion and conclusion section).

\section{Discussion and conclusion}

In general, large scale disturbances in forests, especially windstorms, may temporally interrupt continuity of carbon sequestration in biomass of forest cover (e.g. Seidl et al. 2014). The length of subsequent restoration of carbon stock fixed in tree biomass depends on the rate of forest regeneration and productivity of newly-arisen stands. Our results showed that one decade after the wind disaster, the total carbon amount fixed in the aboveground biomass of trees was about 6,600 $\mathrm{kg}$ and 6,200 kg per ha. The previous estimates in this region (Konôpka et al. 2016) showed that the pre-disturbance forests, prevailingly mature spruce stands, contained about $75,000 \mathrm{~kg}$ of carbon per ha fixed in the aboveground tree biomass. It means $11-12$ times more carbon in the aboveground tree biomass in old (pre-disturbance) stands than in young (post-disturbance) stands. Moreover, since our previous paper (Konôpka et al. 2016) showed the tree carbon stock at the same transects in spring 2015, we can comment on the inter-annual changes. As for the DD transect, the carbon stock in the aboveground tree parts increased by $38 \%$ that is a really huge change. The increase at the HS transect was only by $19 \%$ because of the reduction of the number of trees by the thinning treatment in the autumn 2015 (the felling decreased the basal area by approx. $20 \%$ ). Anyway, the inter-annual comparison at the DD transect suggested a very dynamic accumulation of carbon in young stands on the post-disturbance area. That is surely a great difference compared to old stands which can increase their carbon stock in biomass only by a very few percent. This statement conforms with the conclusions of Gower et al. (1996) that the aboveground net primary production declines with age, which is related mainly to changing respiration intensity and carbon gains of trees over their lifespan (Steppe et al. 2011).

Our results for ground vegetation showed the amount of carbon in their aboveground parts of about $1,900 \mathrm{~kg}$ and $1,400 \mathrm{~kg}$ per ha. This represents the biomass of late successional stages of post-disturbance vegetation (nearly no occurrence of ruderal plant species). The comparison to other studies from the same study area (Križová et al. 2010; Fleischer \& Homolová 2012) showed that this amount is similar to quantities found in the succes- 
sional stages developed approximately $5-6$ years after disturbance. This suggests that the maximum biomass of ground vegetation is accumulated few years after a disturbance, which was also reported by Palviainen et al. (2005). If the observed ground vegetation biomass at our transects is compared to the values of mature sprucedominant stands in the High Tatra region (Križová et al. 2010; Fleischer \& Homolová 2012) or in the Low Tatras (Pavlenda et al.2011), we find that the ground vegetation biomass in mature stands is approx. $6-14$ lower than at the transects.

The measurements at the transects showed that while the tree biomass fixed much more carbon than the ground vegetation biomass, the reverse situation was observed in the carbon flux to litter. Previously (Konôpka et al. 2016) we showed that foliage in old (pre-disturbance, spruce dominating) stands made only $6 \%$ of aboveground tree biomass. This equals approximately $900 \mathrm{~kg}$ of carbon per ha annually lost from trees by annual foliage fall. Our estimates for young post-disturbance stands showed the values of carbon by one third lower. However, if we consider litter originating from ground vegetation, larger amount of carbon rotating via annual fall can be assumed in postdisturbance than in pre-disturbance areas. Our finding concerning much higher portion of annual foliage fall to total aboveground tree biomass in young stands than in old stands conforms to the results of Zhou et al. (2006). Their general model showed that the proportion of NPP allocated to foliage decreases and to stem increases with stand age until approximately $40-50$ years, and then the proportions of biomass allocated to individual tree components become stabilised.

We would like to point out that our study focused exclusively on the aboveground part of biomass (i.e. living parts of plants) omitting not only belowground parts (roots) of trees and ground vegetation but also necromass (dead parts of plants). As for roots, their higher contribution to total plant biomass might be expected in ground vegetation in comparison to young trees. For instance, under the conditions of Central Slovakia, Máliš et al. (2013) showed that in Calamagrostis epigejos dominated grass-bush community belowground parts contributed to total biomass by $40-50 \%$. In parallel, Konôpka et al. (2013) estimated the contribution of roots in a young spruce stand at the same site to the total tree biomass only between $22-24 \%$. Even much higher proportion of belowground biomass of around $65 \%$ was reported by Palviainen et al. (2005) and Pyšek (1991) from post-disturbance communities of ground vegetation developed at sites of spruce-dominated stands. These results indicate that the contribution of ground vegetation to total biomass (i.e. above- and belowground parts of ground and tree vegetation together) at our transects would be larger than to aboveground biomass. The quantification of carbon fixed in plant necromass is rather complicated. The necromass includes mainly debris of roots, stumps, possibly branches of old (pre-disturbance) trees, foliage litter accumulated on ground as well as young trees perished mostly due to competition in dense tree clusters. However, we were neither able to measure these data ourselves nor we were able to find any results from other papers focused on the post-disturbance territory of the High Tatras.

Moreover, for a complete view on carbon cycling in vegetation cover, respiratory activity via foliage and soil medium should be included. Here, we can suppose certain differences between old and young stands as for foliage respiration, eventually its ratio to net primary productivity. In principal, the ratio of carbon emitted by foliage respiration to carbon invested to building tree biomass decreases with stand age (Mäkelä \& Valentine 2001). On the other hand, we can expect higher soil respiration intensity in young (post-disturbance) than old (pre-disturbance) stands. This assumption is based on the fact that young stands were sparse, and contained many gaps with a high level of solar energy input. That would stimulate especially heterotrophic part of soil respiration (see also Karhu et al. 2014).

Concluding our results, we can state different carbon regimes in the compact old (pre-disturbance) and sparseyoung (post-disturbance) stands in the High Tatra region. The differences were not only in the total amount of carbon fixed in tree biomass, but also in the proportion of carbon from the total tree biomass carbon annually dropped in the form of foliage fall. While the wind disturbance caused the dramatic decrease of carbon stock in the tree biomass, young post-disturbance stands with abundant ground vegetation represented large carbon flux via annual plant fall. In fact, twelve years after the wind disturbance, trees contributed to carbon stock more than ground vegetation. On the other hand, the opposite situation was recorded for carbon flux via annual plant litter that was dominated by annual biomass species (fast carbon turnover, i.e. approx. once a year) in the community of ground vegetation.

\section{Acknowledgements}

The research was supported by the projects APVV-0584-12, APVV-14-0086 and APVV-15-0270 from the Slovak Research and Development Agency. Further it was partly supported by the project QJ1220316 from the Ministry of Agriculture of the Czech Republic.

\section{References}

Dale V. H. et al., 2001: Climate change and forest disturbances. BioSciences, 51:723-734.

Dixon, R. K., Brown, S., Houghton, R. A., Solomon, A. M., Trexler, M. C., Wisniewski, J., 1994: Carbon pools and flux of global forest ecosystems. Science, 263:185-190. 
Fischer, A., Lindner, M., Abs, C., Lasch, P., 2002:Vegetation dynamics in central European forest ecosystems (near-nature as well as managed) after storm events. Folia Geobotanica, 37:14-32.

Fleischer, P., Homolová, Z., 2012: Dlhodobý výskum ekologických pomerov v spoločenstve smrekovcových smrečín vo Vysokých Tatrách po prírodných disturbanciách. Lesnícky časopis - Forestry Journal, 57:237-250.

Gower, S. T., McMurtrie, R. E., Murty, D., 1996: Aboveground net primary production decline with stand age: potential causes. Tree, 11:378-382.

Hansen, E. M., 2014: Forest development and carbon dynamics after mountain pine beetle outbreak. Forest Science, 60:476-488.

Karhu, K., Auffret, M. D., Dungait, A. J., Hopkins, D. W., Prosser, J. I., Singh, B. K. et al., 2014: Temperature sensitivity of soil respiration rates enhanced by microbial community response. Nature, 513:81-84.

Konôpka, B., 2003: Needle traces as indicators of growing conditions Scots pine (Pinus sylvestris L.). Journal of Forest Science, 49:1-10.

Konôpka, B., Pajtík, J., Noguchi, K., Lukac, M., 2013: Replacing Norway spruce with European beech: A comparison of biomass and net primary production patterns in young stands. Forest Ecology and Management, 302:185-192.

Konôpka, B., Pajtík, J., Šebeň, V., Bošel'a, M., 2015: Aboveground Net Primary Production of tree cover at the post-disturbance area in the Tatra National Park, Slovakia. Lesnícky časopis - Forestry Journal, 3:167-174.

Konôpka, B., Pajtík, V., Šebeň, V., 2016: Zmena zásob uhlíka v biomase lesných porastov vo Vysokých Tatrách v dôsledku velkoplošnej disturbancie.Zprávy lesnickeho výzkumu, 61:239-246.

Križová, E., Chovancová, G., Homolová, Z., 2010: Primárna produkcia nadzemnej biomasy bylinnej vrstvy na kalamitných plochách v Tatranskom národnom parku. Zvolen, Acta Facultatis Forestalis, 52:7-25.

Kunca, A., Zúbrik, M., Vakula, J., Galko, J., Konôpka, B., Leontovyč, R. et al., 2016: Výskyt škodlivých činitel'ov v lesoch Slovenska v rokoch 1960-2014, v roku 2015 a prognóza ich vývoja. Zvolen, Národnélesnícke centrum, $139 \mathrm{p}$.

Liechy, H. O., Jurgensen, M. F., Mroz, G. D., Gale, M. R., 1997: Pit and mound topography and its influence on storage of carbon, nitrogen, and organic matter within an old-growth forest. Canadian Journal of Forest Research, 27:1992-1997.

Lindroth, A., Lagergre, F., Grelle, A., Klemedtsson, L., Langvall, O., Weslien, P. et al., 2009: Storms can cause Europe-wide reduction of forest carbon sink. Global Change Biology, 15:346-355.

MacDicken, K. et al., 2015: Changes in Global Forest Resources from 1990-2015. Special issue of Forest Ecology and Management, 352:1-145.
Máliš, F., Konôpka, B., Mal'ová, M., 2013: Post-harvest biomass stock and productivity of Calamagrostis epigejos community under beech and spruce forest stands. Lesnícky časopis - Forestry Journal, 59:197202.

Máliš, F., Fábry, R., Vodálová, A., 2015: Vývoj vegetácie smrekových lesov s rôznym manažmentom po vetrovej kalamite. In: Fleischer, P., Homolová, Z., Šturcel, M.: Štúdie o Tatranskom národnom parku, 11:207-217.

Mäkelä, A., Valentine, H. T., 2001: The ratio of NPP to GPP: evidence of change over the course of stand development. Tree Physiology, 21:1015-1030.

Moran, A. et al., 2010: Climate Change. The Facts. Institute of Public Affairs of Australia, Victoria, 135 p.

Report on Forestry in the Slovak Republic 2015 - Green Report, 2016. Bratislava, Ministry of Agriculture and Rural Development of the Slovak Republic, $76 \mathrm{p}$.

Nikolov, Ch., Konôpka, B., Kajba, M., Galko, J., Kunca, A., Janský, L., 2014: Post-disaster forest management and bark beetle outbreak in Tatra National Park: Mountain Research and Development, 34:326-335.

Økland, B., Nikolov, C., Krokene, P., Vakula, J., 2016: Transition from windfall-to patch-driven outbreak dynamics of the spruce bark beetle Ips typographus. Forest Ecology and Management, 363:63-73.

Palviainen, M., Finér, L., Mannerkoski, H., Piirainen, S., Starr, M., 2005: Changes in the above-and belowground biomass and nutrient pools of ground vegetation after clear-cutting of a mixed boreal forest. Plant and Soil, 275:157-167.

Pavlenda, P., Pajtík, J., Priwitzer, T., Bošel'a, M., Capuliak, J., Durkovičová, J. et al., 2011: Monitoring lesov Slovenska. Projekt FUTMONT, ČMS LESY 2010. Zvolen, Národné lesnícke centrum - Lesnícky výskumný ústav Zvolen, 205 p.

Pyšek, P., 1991: Biomass production and size structure of Calamagrostis villosa populations in different habitats. Preslia, 63:9-20.

Sander, C., Eckstein, D., 1994: Reconstruction of the foliation of Picea abies by means of needle traces. Scandinavian Journal of Forest Research, 9:311-315.

Schmidt-Vogt, H., 1977: Die Fichte. Band I. Taxonomie, Verbreitung, Morphologie, Ökologie, Waldgesellschaften. Parey, Hamburg, 472 p.

Seidl, R., Schelhaas, M. J., Lexer, M. J., 2011: Unraveling the drivers of intensifying forest disturbance regimes in Europe. Global Change Biology, 17:2842-2852.

Seidl, R., Schelhaas, M.-J., Rammer, W., Verkerk, P. J., 2014: Increasing forest disturbances in Europe and their impact on carbon storage. Nature Climate Change, 4:806-810.

Steppe, K., Niinemets, Ü., Teskey, R. O., 2011:. Tree size-and age-related changes in leaf physiology and their influence on carbon gain. In: Size-and age-related changes in tree structure and function. Springer Netherlands, p. 235-253. 
Swanson, M. E., Franklin, J. F., Beschta, R. L., Crisafulli, C. M., DellaSala, D. A., Hutto, R. L. et al., 2011: The forgotten stage of forest succession: early-successional ecosystems on forest sites. Frontiers in Ecology and the Environment, 92:117-125.

Šebeň, V., 2011: Prirodzená obnova po kalamite z novembra 2004 vo Vysokých Tatrách. In: Výskum smrečín destabilizovaných škodlivými činitel'mi. Zvolen, Národné lesnícke centrum, p. 297-308.

Šoltés, R., Školek, J., Homolová, Z., Kyselová, Z., 2010: Early successional pathways in the Tatra Mountains (Slovakia) forest ecosystems following natural disturbances. Biologia, 65:958-964.
Thorsen, J., Mavsar, R., Tyrväinen, L., Prokofieva, I., Stenger, A., 2014: The Provision of Forest Ecosystem Services. European Forest Institute, Joensuu, 73 p. Vološčuk I., Bohuš, I., Bublinec, E., Bohušová-Hradiská, H., Drdoš, J., Dúbravcová, Z. et al., 1994: Tatranský národný park. Martin, Gradus, 557 p.

Williams, C. A., Vanderhoof, M. K., Khomik, M., Ghimire, B., 2014: Post-clearcut dynamics of carbon, water and energy exchanges in a midlaltitude temperate, deciduous broadleaf forest environment. Global Change Biology, 20:992-1007.

Zhou, X., Peng, Ch., Dang, Q. L., 2006: Formulating and parameterizing the allocation of net primary productivity for modeling overmature stands in boreal forest ecosystems. Ecological Modeling, 195:264-272. 